\title{
Implications from the Use of ICT by Language Teachers - Participants of International Projects
}

\author{
Elżbieta Gajek \\ Institute of Applied Linguistics, University of Warsaw, Poland
}

Copyright (c) 2015 Horizon Research Publishing All rights reserved.

\begin{abstract}
Telecollaboration in international school projects requires various competences from the participating teachers. A combination of intercultural, linguistic, technical and subject competences builds ground for successful team work with foreign partners. This article presents a survey on the use of ICT by language teachers, their attitudes to ICT and strategies of professional development, and ways of dealing with problems. On the basis of their opinions implications are drawn which might be applicable beyond the Polish context.
\end{abstract}

Keywords Language Learning Technology, Teacher Training, Projects

\section{Introduction}

School telecollaborative projects via technology have attracted many teachers at all educational levels. There are many examples of successful e international work of this kind at primary and secondary school levels. Yet, the majority of language teachers still refrain from participating in such projects. The aim of this research was to observe language teachers' use of ICT for professional purposes, their strategies of professional development, and the ways of dealing with technical problems. On the basis of a survey on 264 language teachers who take part in international projects, I present factors influencing their teaching strategies, insights into their teaching context related to ICT, and implications for language teachers, teacher trainers, policy makers, school authorities, educational materials and equipment suppliers.

This research is grounded in a long tradition of investigation into the qualities of teachers including good teacher and teachers innovators. Personality traits such as basic mental integration and health and professional attitudes and skills remain unchanged $(22,3)$. However, new areas of research have been opened by new learning environments created by the use of information and communication technologies.

With the invention of educational technology stages of its adoption in education were investigated. Knezek and Christansen (12) developed a six-stage model of technology adoption by teachers. At Stage 1: Awareness, the teacher knows that technology exists but does not use it. At Stage 2: Learning the process, the teacher tries to overcome frustration caused by the first attempts to use ICT. At Stage 3: Understanding and application of the process, the teacher manages to invent ICT-based tasks useful in his or her teaching context. At Stage 4: Familiarity and confidence, the teacher gets some confidence in using ICT, which makes the process more comfortable. At Stage 5: Adaptation to other contexts, the teacher perceives the computer as a tool and focuses more on its functionality than on the technology. ICT becomes a didactic aid. At Stage 6: Creative application to new contexts, the teacher is able to integrate technology into the curriculum and creatively apply it in the classroom.

Another taxonomy explains general attitudes to any innovations introdced into practice. The technology adoption life cycle divides the population into five segments: innovators, early adopters, early majority, late majority and laggards $(10,18, \mathrm{p} 11,7, \mathrm{p} 116)$. Among teachers the first two groups started successful telecollaboration nearly at the moment it was technically possible, but the majority teachers from the last two groups are still reluctant. As the teacher is the most powerful person in the classroom to decide, she or he either introduces international communication authentic or refrains from it. As for a language teacher the technology may be one of the main obstacles in starting telecollaboration. Other potential barriers for teachers of many subjects such as low language proficiency, or lack of intercultural competence and experience may not be influential in the case of language teachers.

Teachers who are at least at stage 3 try to include telecollaborative projects in their practice. This process started from the very beginning of the conceptual approach to the Internet as an educational tool for learning languages it has been perceived as a medium of collaboration of language learners and teachers $(20,13, \mathrm{p} 170-172)$. First, successes of tandem work through asynchronous email exchange initiated and supervised by language teachers were reported $(19,6)$. Then, with the development of ICT the effectiveness of asynchronous communication between students was 
investigated. Further progress in voice and picture transmission encouraged teachers to use messengers for synchronous oral and video communication $(14,12)$. The main concern of researchers who investigated the phenomenon of such ICT-based collaboration were the linguistic effects such as progress in writing and reading skills $(1,16)$. Intercultural aspects of telecollaboration were also emphasized (15). Chapelle (5) stressed the role of a cross-cultural perspective on telecollaboration, which has roots in Vygotskyan cultural psychology (21) that "makes sense of 'learning' by reference to the social structure of activity" (4). At any stage of its development technology is reported as unreliable or as a source of organizational problems, thatis why technical issues are usually presented as difficulties. However, despite its limitations ICT does serve as the main medium of collaboration in such projects.

European eTwinning programme is an educational environment which supports teachers willing to undertake telecollabrative projects. It also opens a new area for research on learners and teachers. A recent study on eTwinning projects was focused more on the overall impact and role of the programme in the participating schools, and on the pupils and teachers than on explaining various factors influencing ICT-based language learning and teaching processes in school projects (17). Its outcomes were highly positive and showed a positive picture of the role of eTwinning projects. However, this study does not provide insight into a context in which an individual teacher works and the factors that encourage him or her to participate in such projects or refrain from taking part in such activities. Thus, a further investigation into the profile of a teacher who initiates students' telecollaboration or participation in international projects may provide insight into the perceptions and motivations that drive teachers towards participation in such projects.

The study is a continuation of longitudinal studies on teachers of languages started in the year 2000 and continued in 2005 to identify changes in teachers' opinions and attitudes towards technology over the years (7). This chapter presents various aspects of the use of ICT for professional purposes by language teachers who participate in the international projects in order a profile of a teacher participant in such projects.

\section{Research Context and Aims}

The context for this study covers the situation in which language teachers are convinced that the pedagogical ground of their teaching practice is communicative approach which stresses interactions, authentic communication, information gap and meaningful situations. When the grounds for the communicative approach were established in the 70s and $80 \mathrm{~s}$ of the last century, the Internet was a reality only in the visionary minds of American scientists and military officers who just started establishing technical protocols of the net. Nowadays, ICT provide an environment for communication of language learners. International school collaboration for language learning purposes fulfills the fundamental requirements of the communicative approach. The research questions cover the following areas: (a) What technology is used by the teachers? (b) What do they do with the technology? (c) How often do they use technology for selected activities? (d) How do they develop professional skills and knowledge? (e) How do they deal with problems? (f) Are there any sources of anxiety? (g) How do they assess the role of international communication in language teaching?

\section{Methodology}

\section{Subjects and Research Procedure}

620 language teachers participated in the study from March to April 2013.They constitute $0,95 \%$ of the population of language teachers in Poland (the total is 70662), among them of 264 respondents took part in international telecollaborative projects. The respondents answered questions distributed through the newsletter of the Foundation for the Development of the Polish Education System. As the article aims at investigation of the teachers participating in telecollaborative projects, the number of 264 is taken as $100 \%$. So, all of them were active participants in either eTwinning or Commenius projects. As the survey was distributed online, all respondents had access to the hardware and software required. $71.8 \%$ had access to a computer, $86.3 \%$ to a laptop, and $52.5 \%$ to both of them. The survey covered various aspects of using technology for professional purposes as well as the teachers' opinions on the use of ICT in teaching languages.

$92.8 \%$ of the respondents were women. $79.9 \%$ were teachers of English, 14.0\% were teachers of German, $6.1 \%$ were teachers of French, Italian or Spanish. The teachers came from all regions of Poland, however two voivodships were better represented that is Silesia $15.5 \%$ with of the respondents and Mazovia with 12.8\%. They worked at various educational levels: $34.5 \%$ at lower primary level, $47 \%$ at upper primary, $49.2 \%$ at lower secondary, and $23.48 \%$ at upper secondary. The numbers do not sum to 100 as many respondents worked at more than one educational level. $42.8 \%$ were between $25-35$ years of age, $36 \%$ between $36-45$, and $15.9 \%$ between 46 and 56 .

\section{Results}

\section{Access to Equipment}

The respondents declared access to the following hardware: computer $73.9 \%$, laptop $88.3 \%$, notebook $22 \%$, mobile device $32.2 \%$, and an interactive whiteboard in class $67.8 \%$.All of them had access to at least one type of hardware. The mean of number of devices used by one respondent is 2.4 . 


\section{The Use of Technology}

The respondents use social media $-67.1 \%$. They create video documents $(47.7 \%)$ and photo documents $(86 \%)$, listen and read electronic texts in the language they teach $(86.7 \%)$ and their native language $(53.4 \%)$.

As various hardware and software tools are used for international project work it is essential to identify the tools and frequency of their use. $50.8 \%$ of the respondents use PowerPoint at least once a week, but only $8.7 \%$ on a daily basis. Two thirds $(66.7 \%)$ use electronic dictionaries at least once a week. $55,7 \%$ of them use the interactive whiteboard at least once a week, and $22.4 \%$ among the total use the interactive whiteboard every day. $26.1 \%$ of the respondents do not use an interactive whiteboard at all. $34.5 \%$ of the respondents do not have access to computers at school as they are located in the IT school labs where only IT lessons are conducted. $41.4 \%$ use ICT for communication with foreign partners at least once a week. $13.6 \%$ of them use it for project videoconferences. $20.8 \%$ use ICT for games. Among them $64.8 \%$ use games with children at lower primary educational level, $27.4 \%$ at upper primary level, $21.4 \%$ at lower secondary level and $13.2 \%$ at upper secondary level.

$50.8 \%$ declared that they knew how to teach a lesson with a foreign partner via a videoconference. $17.1 \%$ do it once a month and $28.8 \%$ do it once a year. $13.6 \%$ do it regularly at least once a week.

\section{Development of Professional Skills and Knowledge}

$73.9 \%$ did not gain professional ICT skills during their qualification courses at the university versus a mere $1.7 \%$ who did. $25.4 \%$ get activities for students from teachers of the same subject and $29,2 \%$ learn from their foreign partners. $15.9 \%$ make use of methodology books, and $20.8 \%$ use professional magazines for language teachers. $97.7 \%$ search the internet for teaching tips, but only $48,9 \%$ participate in professional teachers' fora. $77.3 \%$ use prompts gained during eTwinning or Comenius training sessions. $86.7 \%$ of the respondents learn by doing - working out tasks for learners independently.

\section{Dealing with Problems}

While facing technical problems $6.4 \%$ leave the problems unsolved, while $75.8 \%$ disagree with the statement that they "leave the problem unsolved". $77.7 \%$ solve the problem by themselves. $59.9 \%$ consult the problem with other teachers, $78.9 \%$ with friends and family members, $16,7 \%$ with foreign partners. $78.9 \%$ search the internet for a solution' and $26.2 \%$ make use of professional teachers' fora. $34 \%$ stop using ICT to achieve the aim of the lesson when problems appear. In an open question a few respondents mentioned a helpful IT teacher, a few upper secondary school teachers ask students to solve technical problems and admit effectiveness of students' help.

\section{Sources of Anxiety}

Students' computer literacy is not a source of anxiety for the teachers. $84.5 \%$ of the respondents disagree with the statement: "I'm afraid that the students destroy the equipment during my lesson" and $85.6 \%$ disagree with the statement: "Students are not competent enough to use computers for learning the language". 55.7\% do not feel discouraged by the frequent unreliability of computer technology. 94.3\% disagree with the statement that "the use of ICT in a language lesson is a waste of time" which indicates their positive opinion on the effectiveness of technology usage in class. They are confident computer users, as $96.2 \%$ of the respondents disagree with the statement "I do not have basic computer skills".

\section{Role of Telecollaboration in Language Learning}

$89.8 \%$ agree with the statement that "Languages should be taught in communication with other learners abroad - also via ICT". What is more, $96.6 \%$ agree that "Communication with foreign partners motivates learners to learning languages".

\section{Complementary Data from the Open Questions}

On the one hand, the answers to open questions provide insights into specific use of technology. The respondents mention that they use technology according the learners' needs. One of the respondent notices that she communicates with foreign partners from home, and project work is uploaded from her private computer. Although her learners participate in a telecollaborative project, she does not use ICT in class.

On the other hand, there are various problems the respondents face. They have limited access to technology as the school computer labs are occupied by IT lessons. Movable interactive whiteboards are not convenient because they require calibration, so the teachers avoid using them. Only teachers who have access to interactive whiteboards in their classrooms do not complain about access to technology. Minor technical problems that occur frequently are solved by the teachers themselves or with the help of learners. Headmaster's negative attitude towards technology is also a frequent problem. Some parents express negative attitude to homework based on the internet.

\section{Discussion of the Results}

As the data were collected through an online questionnaire there were no respondents at the first level of technology adoption. The majority of teachers overcame the frustrations characteristic to the second level. On third, that is $29.1 \%$ of the respondents reported learning didactic techniques, so they were at least at stage 3 . They also understood the role of technology in teaching, however, its use depends on the accessibility to resources and educational level they work at. They perceived themselves as competent computer users, which may indicate the fourth stage of technology adoption. If the access to digital infrastructure is convenient the teachers move to the fifth stage of technology adoption. But 
only some of the respondents conducted videoconferences with foreign partners, which placed them at level 6 .

The data collected are complementary to the results of content analysis of the tools used by participants of eTwinning programme. The list in the attachment shows a variety of web-based software creatively applied by the teachers in various projects at all stages of project development. .A detailed analysis of the pedagogy of using each item is beyond the scope of this article.

The results of the survey lead to the profile of the teacher who participates in an international telecollaboration project. She is a woman aged 25-45, teaching English, working at lower secondary or upper primary level. She has access to two pieces of equipment that is an e computer, a laptop or a notebook either at school or at home. Two out of three of her colleagues also have access to an interactive whiteboard. She uses social media, takes photos, listens to and reads texts in the language she teaches. The use of ICT is appropriate to the students' needs. Electronic dictionaries are used most often. In the case of working with lower primary children she uses games more often. PowerPoint presentations and the interactive whiteboard are also used regularly. Communication with partners is also regularly done in class. However one teacher declared that she communicates with foreign partners almost every day, but from home. Another teacher explained that she does the project work after class with pupil volunteers, but does not use ICT in class as ICT-based work is perceived as play not as serious teaching by her supervisors.

The results show that the teacher participant in international projects perceives herself as a competent computer user, who also appreciates students' computer skills. However, she did not learn how to use ICT during qualification courses at university. She is an autonomous, independent learner. She searches the Internet for teaching tips, and solution to problems. She learns by doing, or through training provided by the eTwinning National Support Service. Less frequently she uses methodology books or professional magazines for teachers and learns from foreign partners. Cooperation with teachers of the same subject is not common. Cooperation with foreign partners is focused on project work itself as the respondents do not perceive it as a form of professional development or support in solving problems.

When facing a technical problem she does not leave it unsolved. Even the frequent unreliability of technology does not discourage her from using ICT. The main strategies of dealing with problems are searching the Internet and looking for support among friends and family members. Depending on the IT teacher's readiness to cooperate, she makes use of his/her knowledge and skills. She is convinced of the motivational role of communication with foreign partners, and that languages should be also taught in such communication.

The answers of the respondents are coherent, as teachers who do not have the interactive whiteboard also declare that they do not use any. What is more, the teachers who do not have access to ICT in class complain that this is because the school lab is occupied by IT lessons.

\section{Implications of the Study beyond the Polish Context}

The crucial factor influencing teachers' activity is convenient access to technology which is the main concern of equipment suppliers, and school authorities. It turned out that an interactive whiteboard is a trigger as it provides the language teacher with a computer and a beamer in her class. As the respondents are well equipped with the basic types of computers, the next step is to provide them and their pupils with tablets with mobile applications and access to school-wide wifi.

The project work is a teaching technique mainly used with upper primary and lower secondary school learners, as pupils at the age of 11-15 are most responsive to contact with peers, also coming from foreign countries. Interactions with project partners motivate learners to learning a foreign language. The fact that projects are mostly undertaken at these educational levels coincides with the opinion expressed (explicitly) by nearly all respondents that communication with foreign partners motivate pupils to learn the target language and languages should be taught in communication with others. This confirms the methodological grounds of the communicative approach and the Vygotskyan concept of social learning. This implies a shift in teacher training with emphasis on collaborative project work in language teaching methodology.

Teachers practitioners get the most effective and appreciated training from the National Support Service, as academic institutions have failed to equip even the youngest teachers with necessary ICT skills strictly related to language teaching pedagogy and methodology. Thus, emphasis has to be put on the initial pre-service teacher qualifications. As the teachers use the Internet most often as a source of professional materials this indicates a decline in the role of methodology books and professional magazines for language teachers, unless they are available online. Teacher training programmes need to emphasise the role of Internet as a resource in ongoing language teacher professional development. Strategy training in ICT-based teacher lifelong self-education should constitute an essential part of both pre-service and in-sevice training. This implies the need to provide pre-service teachers and their trainers with a variety of ready-made materials for class as well as with teaching tips. What is more, teachers of English are privileged in comparison with teachers of other languages as there are more internet materials for them.

Professional development through projects is orientated on gaining confidence in the use of technology for language teaching purposes and its creative application in the specific teaching context. As $16.7 \%$ consult technical problems with their foreign partners, either the teacher is ICT-literate enough - almost all of them claim they are competent 
computer users or local technical support (other teachers, IT teacher, family, friends and students) is sufficient enough.

\section{Conclusions}

The investigation into the profile of a teacher - participant in an international project shows a coherent - to the extent a questionnaire as a research instrument allows - picture of the respondent who is a teacher innovator or early adopter, may be a role model for other teachers. Every teacher may use the role model to compare his or her own opinions, perceptions and situations by asking questions: Am I confident enough to apply technology in the curriculum and use it creatively? Can I adjust the type of software and hardware to the students' needs, e.g. applying more games with young learners and more contact with peers for teenagers? What can I change to make sense of learning the target language for my learners? How can I use access to the equipment available at school and at students and teachers' homes? What can I do to improve access to ICT? Everyday use of technology means that ICT has reached, in the particular class, the stage of normalization defined by Bax (2) and is not perceived as a waste of time. Do I perceive ICT-based language lesson as equally or even more effective in comparison with a lesson based on other resources. Do I know and appreciate students' ICT skills and competences? What is my reaction to frequent problem with technology? Am I ready to solve the problems with the use of all available human and Internet resources? To what extent the frequent problems discourage me from using ICT? Am I able to solve most of the problems by myself? How can I reduce the level of anxiety related to the use of ICT in class?

With regard to professional development the research shows that pre-service qualification courses do not equip language teachers with necessary ICT skills and competences. So the questions to answer are the following: Where can I find useful resources for professional self-education? What strategies do I use to find teaching tips on the Internet?

To conclude, the research shows that the main ICT-related factors influencing regular use of ICT by teachers participating in international school projects are the following: comfortable access to technology, confidence in own ICT skills and perseverance in dealing with technical problems, willingness to use the Internet as a professional development tool and strong appreciation of the motivational role of international communication and collaboration of teenagers via ICT in order to make sense of learning. All the factors imply the key directions in teacher training for pre and in-service language teachers. The results may be also of interest of policy makers, educational materials and equipment suppliers, as well as for teachers as a trigger for reflection, which may indicate how innovative as teachers they are or what they can do to make progress in their own self-directed professional development.

\section{Attachment}

List of software used by participants of eTwinning projects

\begin{tabular}{|c|c|c|}
\hline Accuweather & JigsawPlanet & Proshow \\
\hline Adobe & Jing & Purpose Games \\
\hline Animoto & Kahoot & Quizlet \\
\hline AnswerGarden & Kizoa & ReadWriteThink \\
\hline Any video converter & KwikSurveys & screedbot \\
\hline Audacity & LCD Text generator & ScribbleMaps \\
\hline AuthorSTREAM & LearningApps & Scribd \\
\hline Blaberizzer & Lino & SketchToy \\
\hline blog & Littlebirdtales & Skype \\
\hline Blog spot & Masher & Sliderocket \\
\hline Bomono & Max Console & Slideshare \\
\hline bookemon & Media ImpressionVoki & SlideTalk \\
\hline Calameo & MIND42 & Smart Notebook 11 \\
\hline ClassDojo & Mindmeister & Smilebox \\
\hline ClassTools & Mindomo & SmileBox \\
\hline Comic Life & Monkey Jam & Smore \\
\hline Comic Master & Moovly & SodaHead \\
\hline Crazy Talk & Movie Maker & Sony Vegas \\
\hline DomoAnimate & MS Excel & Spicynodes \\
\hline DomoNation & MS PowerPoint & Storybird \\
\hline
\end{tabular}




\begin{tabular}{|c|c|c|}
\hline Dvolver & MS Word & Storybord \\
\hline Educaplay & OneTrueMedia & Surveymonkey \\
\hline Elfyourself & ooVoo & Tagxedo \\
\hline e-mail & Padlet & Thinglink \\
\hline ESLvideo & Paint & ToonDoo \\
\hline Fipsnack & Pearltrees & Trip Advisor \\
\hline Flash Gear & Photo Peach & Tripline \\
\hline Flashmeeting & Photo Puzzle Maker & Typeform \\
\hline FlashVortex.com & Photobucket & Vacaroo \\
\hline FlickDraw & PhotoPeach & Vcasmo \\
\hline Flickr & Photoshop & Videojug \\
\hline FormatFactory & Photoshow & Vimeo \\
\hline Fotobabble & Photosnack & VocabularySpellingCity \\
\hline Fotor & Picasa Web Album & Vocaroo \\
\hline Freeonlinesurveys & Picture Manager & VoiceThread \\
\hline Gimp & Picture Trail & Voki \\
\hline Glitter Graphic & PinnaclePaint & Voxopop \\
\hline Glogster & Pixorial & WeTransfer. \\
\hline GoAnimate & Pixrl & WhatsUp \\
\hline Google docs & Pixton & Wondershare \\
\hline Google earth & Pizap & Word Cloud \\
\hline Google maps & Polldaddy & Worditout \\
\hline Iclone v.2 & PollSnack & Wordle \\
\hline Iclone v.4.1 & Popplet & WordPicasa 3 \\
\hline ImageChef & Postmywall & Wordsearchmaker \\
\hline imgur & PowToon & YouTube \\
\hline IrfanView & Powtoon & Zondle \\
\hline iSpring & Prezi & ZooBurst \\
\hline Isuu & ProProfs & \\
\hline
\end{tabular}

[6] Gajek E. E-mail for English. Network. 20003 (1): 9-12.

\section{REFERENCES}

[1] Ayoun D. Write from the start! E-mail for beginning French Students. In: M. Warschauer M. editor Virtual connections: online activities and projects for networking language learners, Honolulu, HI: University of Hawaii Second Language Teaching and Curriculum Center. 1996 41-43.

[2] Bax S. CALL - past, present and future. System. 2003 31(1): 13-28.

[3] Bishop W. E. Successful teachers of the gifted. Exceptional Children 1968 34: 317-325.

[4] Crook C. Computers and the collaborative experience of learning. London Roultedge; 1994.

[5] Chapelle A.A. Is networked-badsed learning CALL? In: Warschauer M., Kern R., editors. Network-based teaching: Concepts and Practice. Cambridge: Cambridge University Press, 2000 204-228.
[7] Gajek E. Edukacja językowa w społeczeństwie informacyjnym. Warsaw: Wydawnictwo Instytutu Lingwistyki Stosowanej; 2008.

[8] Gajek E. Jawne i ukryte cele współpracy międzynarodowej w programie studiów humanistycznych. In: Banachowski L. Postępy e-edukacji. Warsaw: Wydawnictwo Polsko-Japońskiej Szkoły Technik Komputerowych, 2010 p. 113-120.

[9] Gajek E. Interkulturowe QQanie polsko-chińskie. EduAkcja. Magazyn edukacji elektronicznej 20122 (4): 69-79.

[10] Geoghegan W. Stuck at the Barricades: Can Information Technology Really Enter the Mainstream of Teaching and Learning? Change 1995 27(2):22-30.

[11] Jaffe D. Institutionalized Resistance to Asynchronous Learning Networks. JALN [Internet] 1998 2(2), September [cited 2007 Dec 1] Available from http://www.sloan-c.org/publications/jaln/v2n2/v2n2_jaffee.a $\mathrm{sp}$.

[12] Knezek G., Christansen R. The importance of Information 
technology Attitudes and Competencies in Primary and Secondary Education. In: Voogt J., Knezek G., editors. International handbook of information technology in primary and secondary education. New York: Springer; 2008 p. 321-331.

[13] Levy M. Computer Assisted Language Learning. Oxford: Clarendon Press; 1997

[14] Lewis T., Walker L., editors. Autonomous language learning in tandem. Sheffield: Academy Electronic Publications; 2003.

[15] O'Dowd R. Telecollaboration and the development of intercultural communicative competence. München: Langenscheidt-Longman; 2006.

[16] Schultz J.M. Computers and Collaborative writing in the foreign language curriculum. In M. Warschauer, Kern R., editors. Network-based teaching: Concepts and Practice. Cambridge: Cambridge University Press, 2000 p. 121-150.

[17] Study of the Impact of eTwinning on the participating pupils, teachers and schools; Final report [Internet] 2013 Luxembourg: Publications Office of the European Union. [cited 2014 Dec 23] Available from http://efc.idnet.net/publications/eTwinning\%20Report.pdf.

[18] Tammelin M. Introducing a Collaborative Network-based Learning Environment into Foreign Language and Business Communication Teaching Action Research in Finnish Higher Education Helsinki: Department of Education. [Internet] 2004 [cited $2014 \mathrm{dec} 23$ ] Available from https://helda.helsinki.fi/bitstream/handle/10138/19988/introd uc.pdf

[19] Warschauer M., editor. Virtual connections: online activities and projects for networking language learners, Honolulu, HI: University of Hawaii Second Language Teaching and Curriculum Center; 1996.

[20] Warschauer M., Kern R., editors. Network-based teaching: Concepts and Practice. Cambridge: Cambridge University Press; 2000.

[21] Wertsch J. V. Vygotsky and the social formation of the mind. Cambridge: Harvard University Press; 1985.

[22] Washburne C. A Living Philosophy of Education. New York: John Day; 1940. 